\title{
Hildegard Elisabeth Keller, ed. Jakob Ruf, ein Zürcher Stadtchirurg und Theatermacher im 16. Jahrhundert. Volume 1
}

Zürich: Chronos Verlag, 2006. Pp. 303, plus 1 CD.

This book takes an unusual and wide-ranging approach to its subject, the Zurich physician and playwright Jakob Ruf (c. 1505/6-1558; also known as Ruef, Rueff, and other variants). It is the first of a planned five-volume series that examines Ruf's life and work in unparalleled detail, and emerges from the Zurich-based research project "Jakob Rufs Theater- und Heilkunst" (2004-2007). This initial volume was released to coincide with an exhibition on Ruf staged in Zurich's Strauhof. It evidently aims to attract the attention of both the German-speaking (especially Swiss) public, and a broader international scholarly community. The book includes a series of nine short essays by five specialists that examine various facets of Ruf's life, environment, and writing. The second half of the volume takes a more unusual direction — reflecting the exhibition project—as it is structured as an alphabetical listing of various key themes and people associated with Ruf's life and work. Some of these are very broad (the meaning of Swiss independence in the sixteenth century), while some are exceptionally narrow (the object known as an Ehelöffel, used to symbolically reunite couples undergoing marital strife). While the connections to Ruf are sometimes tangential, the entries usefully illuminate the cultural, social, religious and intellectual life of mid-century Zurich. The book pays particular attention to Ruf's work as a writer and playwright, and another unusual inclusion is a CD with audio recordings of some of Ruf's own works a well as a number of the primary sources used to reconstruct his life story; primary sources are also transcribed and printed in the book. The distinctiveness of Swiss German is emphasised through an examination of Ruf's use of vivid vernacular phrases in his medical texts and especially his plays. The volume is beautifully produced and illustrated, and the scholarship is both stimulating and careful. Footnotes and bibliography direct the reader to further resources. Nonetheless, scholars would find an index a welcome addition to the volume, particularly given its unusual structure.

The prolific and intellectually versatile Jacob Ruf is an interesting figure for a number of reasons. He rose above the opportunities offered by his birth-his father possibly a baker, and certainly not wealthy-to become a preeminent surgeon (Stadtschnittartzt) and also a respected playwright in Zurich, the city that he settled in around 1531 . His plays were heavily influenced by his commitment to the Swiss Reformation, and include Adam und Eva, Hiob, Wilhelm Tell, and 
the Weingarten, in which the devil plays a prominent role and of which a vividly illustrated manuscript copy is extant. Ruf performed in some of his own plays and also at times took on the role of director. He is, however, best known today as the author of a book on the generation and birth of children: Ein schön lustig Trostbüchle von den empfengknussen vnd geburten der menschen. This "cheerful consolation book on the generation and birth of humans," primarily intended for midwives but also of interest to humanists and physicians, was published in 1554. Ruf's text was in German, the publisher put out a Latin translation in the same year, and both were reprinted a number of times over the folllowing decades. This book includes a useful annotated checklist of all Ruf's known publications. He prepared a number of medical texts, including the unpublished Augenheilkunde of c. 1545 addressing the care of the eyes, and a Tumorbüchlein of 1556 . He wrote broadsheets and calendars providing medical advice and discussing natural wonders, and a study of famous practitioners of medicine and astrology throughout history, part of which was published in 1545 .

Ruf's associates included the prominent naturalist and humanist Conrad Gessner. He was also a contemporary of central figures of the Swiss Reformation like Heinrich Bullinger, and lived in a Zurich shaped by the Reformer Ulrich Zwingli. Zwingli had died in 1531 in the second of the Kappeler Kriegen, the inter-cantonal wars that had arisen from conflicts over religious reform. Although Ruf had not personally fought, the Stadtchirurg of Zurich had been killed in the battle of 1531 and Ruf subsequently moved to Zurich and took up his position. An important and explicit aim of this book is to consider Ruf's life in this context of the upheaval and change that shook the Swiss cantons and the city of Zurich during his lifetime. Historians of Zurich will find the detailed examinations of Ruf's social networks and political and religious engagement useful. That a talented Steinschneider (stone cutter, or simple surgeon) was able to reach an elevated social and economic position in this changing environment, despite not belonging to the university-trained medical profession, is an important and carefully explored issue in this book. Amongst its most interesting components are three essays by Hubert Steinke that examine aspects of the medical profession at this time: what it meant for Ruf to be a surgeon (chirurgien); how to understand his profession relative to work undertaken by barbers and doctors; and practical aspects of his work; all of which will be of considerable interest to historians of medicine.

Ruf is a little-known figure today, and this book usefully fills a gap in scholarship by drawing upon sources not utilised in previous studies to provide as full a picture as possible of his life and work. Individual sections will be of particular interest to 
scholars of Swiss literature and historians of medicine, respectively. Cumulatively, the book presents a stimulating cross-section of cultural history, religious history, medical history and literary studies, and provides a fascinating and richly nuanced picture of the social and professional networks that fostered change and innovation in sixteenth-century Zurich.

JENNIFER SPINKs, The University of Melbourne

\section{Lyrics of the French Renaissance: Marot, Du Bellay, Ronsard}

Translated by Norman R. Shapiro with an introduction by Hope Glidden Chicago: University of Chicago Press, 2006. Pp. xxvi, 384

Shapiro's consummate translations of selected sixteenth-century French lyrics, first published in 2002 in hardback, are now available in paperback. French originals and English translations are given side-by-side, and there are occasional, though not systematic, footnotes about language, poetic form, biography, or historical events. Hope Glidden's introduction provides enough context for non-specialists while offering some thought-provoking insights for more initiated readers. However, one sometimes has the impression that Glidden's text has been truncated or edited; a significantly longer introduction, doing justice to her considerable expertise, would have been preferable. The selection of poems mostly respects the diversity of the poets' output, and includes poems from some collections scarcely read today (Ronsard's Gayetez or Du Bellay's Sonnets divers, for example). The space given to Marot is most welcome; he is presented unequivocally as being as important an influence on vernacular lyric as Du Bellay and Ronsard. The lack of selections from Ronsard's polemical discourses is regrettable, as is the omission of Marot's L'Enfer or his French Psalms. Marot's epigrams, on the other hand, seem overrepresented (70 pages, compared to only 16 pages of his epistles). But the selections made are understandable from a translator's point of view: Shapiro's skills shine most, and he perhaps catches most the spirit of the original, when he is rendering pithy, witty verse. It is as an exercise in translation, and as a gloss on the sixteenth-century practice of imitation itself, that this book is most impressive. Shapiro maintains the rhyme and meter of the original, and otherwise seeks to imitate in the Renaissance sense of the word, acknowledging his debt to his models while not giving slavishly literal equivalents. Readers using the book as a scholarly tool will wish for more apparatus: a bibliography would certainly be helpful, more footnotes, and publication dates for the collections represented. Nevertheless, the 